\title{
Sharecropping and livestock specialization in France, 18301930
}

\author{
JUAN CARMONA*
}

\begin{abstract}
Historians of sharecropping in France have usually emphasized its negative effects on growth and on the workers' welfare. However, from about 1840 the regions of central and western France, regions where sharecroppers were especially numerous, were also areas that saw great improvements and the special ization in commercial livestock. As the author shows, landowners from these areas used sharecropping contracts in order both to seize the opportunities given by the potential scale economies in livestock rearing and to take advantage of family labour at a time of increasing wages. After presenting some basic data regarding share cropping contracts, the second section is intended to describe the improvements in livestock farming in the area under sharecropping after 1840 and the contribution of landowners. Section III offers an explanation of why landowners preferred share cropping to fixed rent contracts. Three causes in particular are identified: (i) a lack of physical and human capital sufficient to allow potential farmers to engage in large scale farming; (ii) the contribution of landlord managerial expertise; and (iii) the fact that the complexity of mixed farming required a quality of work that would have been too expensive with wage labour. In a final section the ways in which the success of sharecropping minimized transaction costs are discussed.
\end{abstract}

The persistence of sharecropping in nineteenth and twentieth century France has been seen as a symbol of the damaging role of inefficient agricultural contracts and traditional customs in French agrarian devel opment. Most contemporaries complained about the poverty of share croppers, the prevalence of subsistence crops, the use of slow and inefficient draft oxen instead of horses and the poor working conditions. The absence of incentives and the under investment in equipment by landowners and sharecroppers have also been advanced as explanations

* Department of Economic History and Institutions, Universidad Carlos III de Madrid. 
to explain the low productivity. ${ }^{1}$ Contemporaries also stressed the laziness of métayers (sharecroppers) and their resistance to innovation. Nineteenth century surveys show that illiteracy rates in departments where the con tract was prevalent were higher than in other areas. The persistence of sharecropping and the predominance of owner occupiers were features of the slow structural change that supposedly explains France's poor agricultural performance before the Second World War. ${ }^{2}$

More recently, and by contrast, it is the rationality of sharecropping that has been the focus of increasing interest for institutional economists. Landowners might prefer sharecropping contracts to rental contracts in situations where farming carried unusually high levels of risk, where tenants were poor and where credit markets were imperfect. This was not just because tenants with rental contracts were likely to default, but also because sharecropping contracts gave landowners the necessary protection to risk lending their tenants the draught animals necessary for cultivation. ${ }^{3}$ The contract would also be preferred in supervision intensive crops to prevent mismanagement of land and capital specific to it, such as build ings, vineyards or trees. Adrien de Gasparin in 1832 argued that this explained the prevalence of sharecropping in the prosperous area of vineyards, olives and fruits in the South of France. ${ }^{4}$ However, farms cul tivated by sharecroppers in central and western France were much criti cized from the mid nineteenth century for their low levels of investment and the poor technical preparation of the tenants. This negative view of sharecropping was contrasted with the supposedly highly successful capitalist farms of northern France. In fact, this argument conceals the fact that from about 1840 the regions of central and western France, such as the Bourbonnais, the Limousin or Maine regions where sharecroppers were especially numerous were also areas that saw great improvements and a specialization in commercial livestock oriented to urban markets. Though it is true that farmers also produced a wider range of products that included grains and forage, a progressively larger share of marketable products came from livestock farming. The fact that a large proportion of sharecroppers' farms were of medium to large size (called métairies), ${ }^{5}$ in a context of substantial peasant holdings, led contemporaries to debate whether the fixed rent tenancy contract, as found in northern France and in England, would not be better for large scale cultivation.

The historical experience is important for explaining the persistence of sharecropping, as it was the predominant contract south of the Loire around $1700 .^{6}$ However, its decline started before the end of the eighteenth century, and there is evidence that the adoption of sharecropping con tracts or the renewal of existing ones in the nineteenth century played a major role in the diffusion of mixed husbandry techniques on the larger 


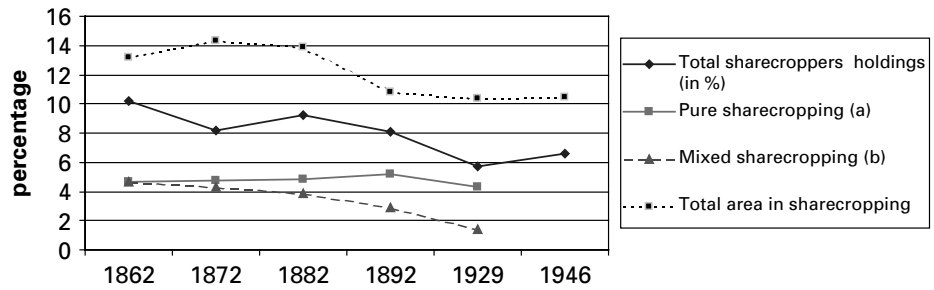

FIGURE 1. Sharecropping in France, 18621946 (in \% of holdings and acreage). (Sources: Ministère de l'Agriculture, du Commerce et des Travaux Publiques, Résultats généraux (Strasbourg, 1868); Statistique Internationale de l'Agriculture (Nancy, 1876); Ministère de l'Agriculture, Résultats généraux de l'enquête décennale de 1882 (Nancy, 1882); Ministère de l'Agriculture, Résultats de l'enquête décennale de 1892 (Nancy, 1897); Ministère de l'Agriculture, Statistique agricole de la France: résultats généraux de l'enquête de 1929 (Paris, 1929); Institut National de la Statistique et des Études Économiques, Recensement général de la population effectué le 10 mars 1946, vol. VII (Paris, 1950).)

farms, in the same way as fixed rent tenancy did in northern France. As I will show, landowners from central and western France used share cropping contracts in order to seize both the opportunities given by potential economies of scale in livestock rearing, and to take advantage of family labour at a time of increasing wages. In this article I examine only livestock specialization on the large farms because, although the majority of farmers produced a wide range of products (including pork, poultry and wool), beef was by far the most important.

I

It is only possible to get an accurate picture of the extent and evolution of land tenure in France from the mid nineteenth century on. As can be seen in Figure 1, the percentage of holdings in sharecropping stayed at around a tenth of all farms during the nineteenth century, and then declined slowly during the first half of the twentieth century. The number of holdings fell from 400,000 in 1852 to 260,000 in 1929 , with the farm area covered by the contract falling from 14 to 11 per cent during the same period. Sharecropping was the most common tenancy contract in several areas south of the Loire, and was completely absent in the North and North east. For many contemporaries of the 1850 s the persistence of sharecropping was seen as a problem, and an obstacle to agricultural improvements, in a period of rapid modernization. ${ }^{7}$ The main criticism was its inefficiency compared to fixed rent contracts. Straightforward evidence of the superiority of the latter was, as many argued, the poverty 
of the South west compared to the prosperous North, where the contract had been completely absent for at least a century. ${ }^{8}$ Whereas those farmers paid a fixed rent in money, and therefore had more incentive to allocate resources and effort on their farms so as to maximize their income, sharecroppers had less incentive to maximize their effort (and landlords to contribute capital), since they received in return only half of the output. ${ }^{9}$ Moreover, landlords were supposedly reluctant to provide expensive machinery or buildings to poor and illiterate tenants, a rational response that would jeopardize land improvements. ${ }^{10}$ This was considered especially problematic in a period when 'l'agriculture amélioré' (the new husbandry) was becoming more capital intensive. ${ }^{11}$ By contrast, sharecropping was defended in periods of crisis, such as during the last decades of the nine teenth century or the 1930s, as a way to rescue farmers from the threat of bankruptcy. ${ }^{12}$ However, the defenders of sharecropping were generally more concerned with its social and moral advantages, rather than any economic ones. ${ }^{13}$

In the last few decades an increasing number of theoretical economists have tried to understand the rationale of contract choice, especially the question of why a supposedly inefficient institution such as sharecropping was so widespread (see the article by Giovanni Federico in this issue). The poverty of potential farmers in a risky activity and the absence, or the imperfection, of credit markets might explain why landowners preferred a share contract to a fixed rent as a way to assure rent payment from poor tenants, while at the same time providing the livestock necessary to cultivate the land. As Philip Hoffman has observed, this helps explain the presence of the contract in poor areas in early modern France, as well as in developing countries today. ${ }^{14}$ But the presence of sharecropping can be explained for completely different reasons, namely as a way to mitigate opportunistic behaviour with crops such as vines, olives or permanent tree crops, because tenants with a fixed rent contract would be tempted to increase their short term output by running down the capital invested. ${ }^{15}$ Moreover, other aspects of the contract can reduce transaction costs and Marshallian inefficiencies. For example, a long term relationship between the principal and the agent (here the landlord and the tenant farmer) has the virtue of allowing commitment by both parties to comply with the contract through the mechanism of reputation, making it as efficient as fixed rent farming. ${ }^{16}$ In the case of early modern France, poverty might explain the presence of sharecropping in the South west of the country, and viticulture its existence in many parts of the South. But are the same explanations valid in France in more recent times?

If the tenant's poverty explains the traditional presence of share cropping, the subsequent increase in wages and overall prosperity of 
French agriculture after 1850 would, in theory, have seen sharecroppers climb the farming ladder and switch to fixed rent contracts. In addition the growth in farm servants' and labourers' savings might allow them to buy their own land and animals. ${ }^{17}$ Indeed, many sharecroppers did move to fixed rent contracts during the nineteenth century. But this process concerned mostly the smallest share tenants called bordiers or closiers in central and western France. ${ }^{18}$ Indirect evidence from government inquiries confirms this trend. The inquiries distinguish between two different classes of sharecropping contract: tenants with no other source of income (pure sharecroppers) and tenants who also cultivated their own land (mixed tenures) and who often farmed much smaller units. Whereas the number of pure sharecropping remained at around 200,000 between 1862 and 1929, mixed tenures diminished from 193,000 to 67,000 over the same period (see Figure 1). In 1929, the size of farms in share tenancy was consistently larger than with any other class of tenure, about twice the average between 1882 and 1929, with the exception of the South east and those regions that specialized in vines. The 1946 farm census identifies both type of contract and size of holding, at a lower administrative level than the department (the région agricole). A sample of régions agricoles where sharecropping was common shows not only that farms were com paratively large but that in these regions landowners everywhere preferred this type of contract for their largest farms (see Table 1). ${ }^{19}$ Most areas included in the sample had a much larger proportion of sharecropping contracts than the rest of the country, but even in regions where the contract was less predominant, such as Bas Berry or Boischaut Sud, (with 9 and 8 per cent of their total agricultural area in sharecropping), most of the largest farms were leased to sharecroppers. The average size of a typical métairie was between 25 and 60 hectares, equivalent to a medium size holding. However, at the end of the nineteenth century, only 6.8 per cent of French farms were above 30 hectares. ${ }^{20}$ Therefore, it seems likely that economies of scale played a significant role in explaining contract choice, and landowners preferred to lease their largest farms to share croppers rather than fragmenting them into smaller units.

As I have noted, both agronomists and economists have also argued that certain kinds of crops help explain the presence of sharecropping. A survey on sharecropping in France in 1953 devotes almost half its space to vineyards, given the wide variety of clauses included in the different contracts. Sharecropping contracts were very common in almost every area with vineyards, especially in Cognac (Charentes), Armagnac (Gers) and Vallée de la Loire (Maine et Loire, Loire Inférieure) and Côtes Chalonnaise, Mâconnaise, Beaujolais (Saône et Loire, Loire, Rhône). ${ }^{21}$ Resin was another crop that explains the persistence of one of the largest 
TABLE 1

A breakdown of large farms by tenurial contract in sample 'régions agri coles' from the Centre west and South west of France in 1946

\begin{tabular}{lccccc}
\hline \hline & $\begin{array}{c}\text { Average size } \\
\text { of the largest } \\
\text { farms } \\
\text { Région agricole }\end{array}$ & $\begin{array}{c}\text { Owner } \\
\text { cultivation } \\
(\%)\end{array}$ & $\begin{array}{c}\text { Fixed- } \\
\text { rent } \\
\text { (départeming } \\
(\%)\end{array}$ & $\begin{array}{c}\text { Share- } \\
\text { cropping } \\
(\%)\end{array}$ & $\begin{array}{c}\% \text { of total } \\
\text { area in } \\
\text { share- } \\
\text { cropping }\end{array}$ \\
\hline Centre-West & & & & & \\
$\quad$ Coteaux (Allier) & 53.9 & 14 & 26 & 60 & 25 \\
Forterre (Allier) & 47.4 & 11 & 29 & 59 & 32 \\
Confolentais (Charente) & 74.9 & 21 & 10 & 67 & 27 \\
Aunis (Charente Maritime) & 57.3 & 32 & 31 & 36 & 10 \\
Marche (Cher) & 58.9 & 22 & 13 & 63 & 12 \\
Bas Berry (Creuse) & 55.9 & 14 & 12 & 72 & 9 \\
Bocage (Vendée) & 48.9 & 6 & 40 & 53 & 19 \\
Montmorillon (Vienne) & 63.2 & 19 & 13 & 64 & 25 \\
Basse Marche (Hte Vienne) & 90.8 & 10 & 2 & 84 & 25 \\
Bourbônnais (Saône-et-Loire) & 57.2 & 11 & 40 & 47 & 23 \\
Boischaut Sud (Indre) & 133.2 & 29 & 25 & 46 & 8 \\
Gatine (Indre-et-Loire) & 91.4 & 22 & 21 & 52 & 22 \\
Elevage (Mayenne) & 38.2 & 12 & 47 & 40 & 22 \\
South-west & & & & & \\
Thore (Tarn) & 78.5 & 25 & 17 & 54 & 24 \\
Lauragais (Hte.Garonne) & 42.9 & 21 & 11 & 65 & 40 \\
Ht.Armagnac (Gers) & 43.7 & 49 & 10 & 40 & 21 \\
\hline \hline
\end{tabular}

Sources: Institut National de la Statistique et des Études Économiques, Recensement géneral de la population effectué le 10 mars 1946, vol. VII (Paris, 1950).

areas of sharecropping in France before the Second World War, being found in the huge pine forests of the Landes (Landes and Gironde in the South west). ${ }^{22}$ However, as Table 2 shows, in 1892 (the date of the only agricultural inquiry which specifies tenure by crops), with the exception of the South east, vineyards made up only a tiny share of the cultivated land in sharecropping (3.94 per cent). Arable land, producing mainly cereals and fodder (78.3 per cent) and pasture (16.99 per cent) were much more common, and explaining why sharecropping was usually associated by contemporaries with 'polyculture' in the twentieth century. ${ }^{23}$ Instead, for many, 'polyculture' was used as a synonym for small scale self sufficient farming, employing family labour ('polyculture familiale'). This, in turn, explains the supposed lack of specialization of risk averse peasants and the persistence of traditional tendency technology. ${ }^{24}$ In fact, it is true that most farmers grew a wide variety of products and that most were 
T A B LE 2

Land use on sharecropping farms in France in $1892(\%)$

\begin{tabular}{lcccc}
\hline \hline & & & & $\begin{array}{c}\text { Market } \\
\text { gardens }\end{array}$ \\
& Arable & Pasture & Vines & gardes \\
Loire & 78.47 & 19.07 & 1.40 & 1.06 \\
Poitou-Charentes & 82.53 & 15.19 & 1.73 & 0.55 \\
Limousin & 67.00 & 32.28 & 0.17 & 0.55 \\
Centre & 80.39 & 16.74 & 2.34 & 0.52 \\
Aquitaine & 75.98 & 16.68 & 6.32 & 1.03 \\
Midi (+ Aude) & 80.37 & 11.33 & 7.72 & 0.58 \\
Rhone & 77.36 & 12.76 & 8.65 & 1.23 \\
Provence & 75.32 & 11.14 & 11.99 & 1.55 \\
Languedoc ( Aude) & 76.50 & 12.82 & 9.40 & 1.28 \\
France & 78.30 & 16.99 & 3.94 & 0.77 \\
France all tenures & 74.53 & 18.90 & 5.20 & 1.37 \\
\hline \hline
\end{tabular}

Sources: Ministère de l'Agriculture, Résultat de l'enquête décennal de 1892 (Strasbourg, 1897).

consumed on the farm, but the largest ones engaged in commercial live stock rearing. As we will see, not only were the largest farms producing mainly meat, but livestock specialization was mainly a sharecropper's activity. ${ }^{25}$ The contract was especially important in France's three large cattle rearing areas: the old provinces of Berry (Allier, Cher, Indre and Nivernais and the western part of Saône et Loire), the Limousin and Poitou (mainly Haute Vienne, Creuse, Vienne and the Charentes) and Maine and northern Anjou (Mayenne, Maine et Loire). These con stituted around 45 per cent of the area under sharecropping in France in 1929 , most of them in large métairies. ${ }^{26}$

As Table 3 shows, in 1840 labour productivity in the areas where share cropping was widespread was well below the French average. ${ }^{27}$ These departments, in part because of the absence of good communication net works, were mostly marginal areas, especially the districts that where dominated by large métairies. But geographical factors were also important for two other reasons: the high clay content of the soil raised the draft animal and labour requirements in cultivation and also lowered yields. ${ }^{28}$ Land could be improved by marling, liming and draining, but these operations required high levels of investment that only market 
TABLE 3

\begin{tabular}{|c|c|c|c|c|c|c|c|c|c|}
\hline \multirow[b]{2}{*}{ Départements (main cattle breed) } & \multicolumn{2}{|c|}{$\begin{array}{l}\% \text { livestock meat in } \\
\text { agricultural production }\end{array}$} & \multicolumn{2}{|c|}{$\begin{array}{l}\% \text { meat in total } \\
\text { agricultural production }\end{array}$} & \multicolumn{2}{|c|}{$\begin{array}{l}\text { Production per } \\
\text { active male }\end{array}$} & \multicolumn{2}{|c|}{$\begin{array}{l}\text { Livestock per active } \\
\text { male (France 100) }\end{array}$} & \multirow{2}{*}{$\begin{array}{c}\text { Land in } \\
\text { sharecropping } \\
\text { in } 1882(\%)\end{array}$} \\
\hline & 1840 & 1892 & 1840 & 1892 & 1840 & 1911 & 1840 & 1892 & \\
\hline \multicolumn{10}{|l|}{ Centre } \\
\hline Allier (Charolaise) & 8.2 & 21.7 & 21.0 & 36.7 & 60 & 134 & 88 & 161 & 41 \\
\hline Cher (Charolaise) & 6.2 & 15.1 & 13.7 & 27.7 & 133 & 122 & 176 & 108 & 35 \\
\hline Saône-et-Loire (Charolaise) & 8.5 & 15.8 & 21.4 & 30.8 & 97 & 95 & 121 & 124 & 18 \\
\hline Nièvre (Charolaise) & 9.0 & 16.3 & 15.5 & 37.5 & 72 & 107 & 95 & 119 & 14 \\
\hline \multicolumn{10}{|l|}{ Limousin-Poitou-Vendée } \\
\hline Corrèze (Limousine) & 6.8 & 12.1 & 22.2 & 34.2 & 51 & 78 & 74 & 83 & 29 \\
\hline Vienne, Haute (Limousine) & 8.2 & 19.6 & 23.8 & 39.2 & 65 & 81 & 106 & 115 & 39 \\
\hline Vendée (Parthenaise) & 9.0 & 17.8 & 14.7 & 25.5 & 112 & 74 & 99 & 134 & 33 \\
\hline Vienne (Parthenaise) & 5.4 & 11.9 & 14.7 & 25.5 & 68 & 112 & 91 & 91 & 30 \\
\hline \multicolumn{10}{|l|}{ Loire } \\
\hline Mayenne (Shorthorn-Mancelle) & 9.2 & 19.8 & 15.6 & 29.5 & 74 & 88 & 142 & 183 & 23 \\
\hline Maine-et-Loire (Shorthorn-Mancelle) & 6.5 & 18.4 & 12.9 & 27.0 & 110 & 92 & 102 & 143 & 19 \\
\hline \multicolumn{10}{|l|}{ South-west } \\
\hline Gers (Gasconne) & 6.1 & 13.9 & 12.6 & 26.4 & 73 & 82 & 74 & 86 & 19 \\
\hline Lot-et-Garonne (Garonnaise) & 7.0 & 16.5 & 14.8 & 28.7 & 92 & 84 & 97 & 113 & 34 \\
\hline Tarn (Garonnaise) & 4.6 & 13.4 & 16.4 & 35.1 & 81 & 108 & 80 & 109 & 34 \\
\hline Tarn-et-Garonne (Garonnaise) & 5.7 & 14.8 & 12.4 & 28.5 & 76 & 109 & 74 & 79 & 25 \\
\hline Average 14 départaments & 7.2 & 16.2 & 16.6 & 30.9 & 83 & 98 & 101 & 118 & 28 \\
\hline France & 4.9 & 11.8 & 10.0 & 23.7 & 100 & 100 & 100 & 100 & 14 \\
\hline
\end{tabular}

Sources: Jean-Claude Toutain, La production agricole de la France de 1810 à 1990: départements et régions. Croissance, productivité, structures (Grenoble, 1988), 868-71. 
opportunities would make profitable. Secondly, summer drought south of the Loire explains the absence of natural and permanent pasture. Both factors explain the high proportion of arable land in low quality cereals such as rye and the large allocation of land left fallow a third of the arable land of the Limousin as late as 1862. Chestnuts still provided a quarter of the rural population's food intake at the end of the eighteenth century. ${ }^{29}$ The poverty of the area explains why animals were poorly fed, and also their low weight. ${ }^{30}$ Only in a few specific areas did farmers have enough feed to fatten their livestock properly, but they were normally finished in Normandy or Charollais, where there were plentiful pastures.

During the second quarter of the nineteenth century two factors pre sented new opportunities for increasing production and productivity in these areas. A growing urban demand caused meat prices to double between 1850 and 1874, providing a strong incentive to specialize in live stock. ${ }^{31}$ At the same time, the large programme of building rural roads that started in 1836 and railway construction not only allowed better access to urban markets, but also considerably lowered the cost of imported inputs (such as marl or lime), giving considerable incentives to special ization in cattle rearing. However, and in contrast to England, over a large tract of the country, and especially in the South, oxen were still used both as work animals and for meat. The fact that oxen and cows were slaugh tered only after a long and hard working life (eight to twelve years was the norm) led to their meat being of very low quality. ${ }^{32}$ When meat started to become more profitable, contemporaries looked at the British model of cattle rearing. In particular, the influential agronomist Onésime Delafond suggested in 1846 the need to introduce three features of British livestock rearing into France. First he encouraged the importation of new breeds from England, particularly the shorthorn the most successful British breed which allowed faster growth and fattening. Delafond also stressed the need to introduce horses in the southern France as work animals, thereby allowing specialization and improving the supply and quality of beef. Finally, he believed that it was crucial to feed animals with a better and cheaper feed ${ }^{33}$ However, a large proportion of the cattle slaughtered more than half a century later were still old draft animals. This lack of specialization proved to have some advantages, such as lower costs of rearing livestock, as farmers could benefit from the manure and work of their animals. Moreover, there was still a certain consensus in France that work animals that had been well fed and reared over five or six years produced meat of good quality. ${ }^{34}$ One of the reasons was the way that the meat was prepared for consumption; as late as 1890 many consumers were still stewing or boiling their meat rather than grilling it, and this suited older beasts. ${ }^{35}$ Contemporaries found that the shorthorn's meat 
had too much fat, and were willing to pay more for the persillé meat (meat with fat marbled in it) that came from the Limousin. ${ }^{36}$

By the turn of the twentieth century farmers were beginning to change the way that beef was produced. First, the working life of draft livestock was shortened so that by 1912 four or five years of light work before slaughter were common, instead of the ten that had been the norm a century earlier. ${ }^{37}$ Secondly, stock was improved through better breeding and the introduction of English cattle, such as the shorthorn (or 'Durham', as it was called in France). ${ }^{38}$ Growers crossed their local breeds with the shorthorn (the 'Charolaise', for instance) or simply improved their ani mals, as 'Limousine' or 'Parthenaise'. ${ }^{39}$ Even if most French breeders were still primarily interested in cattle's aptitude for work, by the late nineteenth century the best animals were bigger, and produced more meat (70 per cent meat instead of 45 per cent a few decades earlier) and they fattened faster. Simultaneously, as in England, French breeders started to create herd books, in order to guarantee the purity of the breed. ${ }^{40}$ Finally, growers increased the output of feed. The introduction of the railways allowed them to marl more cheaply and thereby to reduce the share of fallow land and to reallocate the land gained to the production of forage. This increased the livestock carrying capacity of the land and, as a result, the quantity of dung that was produced to improve soil fertility and raise grain yields. The introduction of marl facilitated the conversion of manure into nitrogen and allowed a shift from subsistence cereals to wheat that could be sold, together with the cultivation of root crops or fodder that was fed to cattle. The absence of good pasture during the summer was partially solved with the introduction of irrigation on pastures in the Bourbonnais, the Limousin and Anjou. ${ }^{41}$

These improvements demanded huge investments in drainage, irrigation, marling, stalls for animals and new buildings. A detailed report published by Jean Augustin Barral in 1884 on irrigation in almost a hundred properties located in the Limousin underlines the high level of this capital investment. ${ }^{42}$ On several occasions, landowners made explicit the distance of their property from the main road and markets, and how railway building provided an incentive to invest in and to reorganize farms. Most farmers had to build reservoirs and to pipe water from rivers (or other sources) to their pastures. Many farms brought water from one or two kilometres away, and invested as much as the price of the land itself. ${ }^{43}$ The building of new barns and stalls was also very costly, once more requiring as much capital as the value of the land itself. ${ }^{44}$ Dressing with marl and lime allowed new land to be cultivated, as well as the reorganization of crop rotations. Similar changes had taken place earlier in other regions such as Mayenne, the Bourbonnais (Allier) or the Vendée. ${ }^{45}$ 
Table 3 shows the results of these major improvements and how most of these areas had reduced the differences in male labour productivity compared to the French average by $1892 .^{46}$ The shift to meat production (including pork and mutton) was very important, and represented an increase of from 17 per cent to 31 per cent of total production. In some cases, such as the Allier or Vienne, where the presence of sharecropping was particularly high, yields increased and specialization was even more spectacular. In 1840, labour productivity in these two departments was below the national average, but by 1892 it was above the average. It is not possible to know to what extent the improvements were due to share cropping and cattle raising, since the unit of analysis, the department, aggregates different agricultural areas. However contemporary studies appear to support the idea that sharecropping made an important con tribution. Barral shows many examples of animal or grain production doubling or tripling as a result of improvements made before the $1880 \mathrm{~s} .{ }^{47}$ Garidel provides similar data for the same period in the Allier and Mayenne. ${ }^{48}$ One consequence of the growth in output was that land prices, were much more resilient than in other areas. In 1914 Caziot, in a com prehensive study of French land prices identified the Bourbonnais as one of the few zones where prices had not fallen in the previous forty years. ${ }^{49}$ Even the Limousin and Poitou showed a small increase in the price of land compared to a fall of 25 to 50 per cent in the main areas of livestock specialization in Normandy, where sharecropping contracts were not used. $^{50}$

It is possible to identify three main reasons that explain why landowners and fermiers généraux ('farmers general', or fixed rent farmers; see below) continued to use share contracts rather than leases of land to fixed rent tenants. The first concerns the absence of sufficient physical and human capital in the form of potential farmers to cultivate large holdings. Most of the improvements mentioned earlier took place in previously marginal and isolated areas, where farmers, as data on illiter acy suggest, probably lacked the necessary skills and information required for introducing technological change. This could explain, secondly, the choice of a contract such as sharecropping which allowed landlords to supply the necessary managerial expertise. And thirdly, the complexity of mixed farming required a quality of work and certain organizational skills that would have been too expensive with wage labour. Family labour, as in the case of owner occupiers, was therefore most appropriate. 
TABLE 4

Sharecroppers' capital in 1875 (in French Francs)

\begin{tabular}{lccccc}
\hline \hline $\begin{array}{l}\text { Dépastement } \\
\text { (région agricole) }\end{array}$ & Livestock & Machinery & $\begin{array}{r}\text { Total } \\
\text { capital }\end{array}$ & $\begin{array}{c}\text { Hectares } \\
\text { per farm }\end{array}$ & $\begin{array}{c}\text { Capital } \\
\text { per hectare }\end{array}$ \\
\hline Centre-west & & & & & \\
Allier (Centre) & 10,000 & 1,500 & 11,500 & 55 & 209 \\
Cher (Centre) & 10,000 & 2,500 & 12,500 & 80 & 156 \\
Indre (Centre) & 8,000 & 500 & 8,500 & 70 & 121 \\
Indre-et-Loire (Centre) & 5,500 & 3,000 & 8,500 & 45 & 189 \\
Mayenne (Loire) & 8,000 & 5,000 & 13,000 & 30 & 433 \\
Corrèze (Limousin) & 3,500 & 1,000 & 4,500 & 35 & 129 \\
Vendée (Loire) & $\mathrm{n} / \mathrm{a}$ & $\mathrm{n} / \mathrm{a}$ & 7,000 & 30 & 233 \\
(Charentes) & 10,000 & 4,000 & 14,000 & 70 & 200 \\
Charente (Charentes) & 2,000 & 400 & 2,400 & 40 & 60 \\
Vienne (Poitou) & 6,000 & & 6,000 & 50 & 120 \\
Vienne, Haute (Limousin) & 7,000 & 3,000 & 10,000 & 35 & 286 \\
Correze (Bas Limousin) & 2,250 & 400 & 2,650 & 20 & 133 \\
South-west & & & & & \\
Dordogne (Aquitaine) & 3,000 & 700 & 3,700 & 30 & 123 \\
Garonne, Haute (Midi) & 3,000 & 1,200 & 4,200 & 18 & 233 \\
Gers (Midi) & 5,000 & 900 & 5,900 & 30 & 197 \\
Landes (Aquitaine) & 2,250 & 1,450 & 3,700 & 16 & 231 \\
Lot (Midi) & 6,000 & 1,200 & 7,200 & 30 & 240 \\
Lot-et-Garonne (Midi) & 3,000 & 500 & 3,500 & 18 & 194 \\
Pyrenées, Basses (Aquitaine) & 1,750 & 850 & 2,600 & 10 & 260 \\
Pyrénées, Hautes (Midi) & 4,000 & $\mathrm{n} / \mathrm{a}$ & 4,000 & 30 & 133 \\
Tarn-et-Garonne (Midi) & 2,500 & 900 & 3,400 & 18 & 189 \\
South-east & & & & & \\
Var & 2,500 & 1,000 & 3,500 & 20 & 175 \\
\hline \hline & & & & &
\end{tabular}

n/a no data available.

Sources: Comte de Tourdonnet, Situation du métayage en France: rapport sur l'enquête ouvert par la Société des Agriculteurs de France (Paris, 1879 1880).

\section{'Métairies' and access to capital}

The capital constraint hypothesis asserts that imperfect or missing capital markets explained the spread of share contracts. ${ }^{51}$ Landlords provided loans and livestock to poor tenants who lacked farm equipment and working capital because they were unable to get loans on the capital market. For French contemporaries, this hypothesis was also the favourite explanation for the absence of the fixed rent contract in the Centre and most of the West and South west. ${ }^{52}$ As I have noted, share croppers often had large farms and the capital requirements for livestock on a modern farm of 3080 hectares could easily reach $6,00024,000$ 
French francs (FF) in 1880, averaging between 60 and 433 FF per hectare (see Table 4). ${ }^{53}$ Landless tenants had limited access to credit markets as their assets were meagre or difficult to use as collateral. Even the large farmers of northern France, better endowed with capital and with special access to credit markets, found it increasingly difficult to obtain finance in the last quarter of the nineteenth century. ${ }^{54}$ The only way to accumulate capital was by way of a formal entitlement, included in all sharecropping contracts, which enabled tenants to get a share of any increment in the stock. The mid nineteenth century literature often identifies the advantages of sharecropping for landless labourers wishing to climb the farming ladder. A popular book for students in rural primary schools emphasized the success of a poor sharecropper called Grand Jacquet, who was finally able to purchase his farm after twenty years of hard work. ${ }^{\mathbf{5 5}}$ But there is evidence to suggest that it was difficult for sharecroppers to accumulate sufficient capital to stock a farm for themselves. For example, the Comte de Tourdonnet complained that sharecroppers usually owned less than a fifth of the total stock. ${ }^{56}$ Even within the favourable figures offered by Garidel for a large farm in the Allier, a sharecropper was able to save 3,600 FF, equivalent to only a quarter of the value of the livestock required for the holding after 23 years on the same farm (1856 1879). ${ }^{57}$ Nevertheless, this was also equivalent to the price of 2.5 to 3 hectares of land in 1879, and would enable tenants to gain their independence, through purchase, as was frequently the case. ${ }^{58}$ This possibility increased in the 1860 s and 1870 s, with higher meat prices, and during the First World War, because of inflation. By contrast, sharecroppers found it harder in periods of low prices. ${ }^{59}$ As sharecroppers became able to buy their own farms, landowners had to look once more for new tenants with no capital or stock. ${ }^{60}$

If capital constraints precluded the possibility of leasing land to inde pendent farmers, why did landlords not split their land into smaller holdings? In France, peasant farming with holdings of 5 to 30 hectares increased in numbers until the end of the nineteenth century, whereas the number of farms of over 40 hectares decreased. ${ }^{61}$ A survey concluded that small farms were increasing their share of agricultural land in more than half of departments, especially in the South, as late as the first decade of the twentieth century. ${ }^{62}$ Moreover, as Levy has shown for England in the nineteenth century, livestock husbandry was associated with much smaller farms than was the case for cereal farming. ${ }^{63}$ One explanation is related to geographical factors: marginal land was often difficult to cultivate with only a couple of cows, the only work animals small farmers normally had.$^{64}$ But the answer is more closely related to the economies of scale re quired for livestock rearing in mixed farming, especially in central western 
France. It was often noted that the new ploughs and machinery required large numbers of oxen to work quickly and efficiently. The new ploughs, such as the Brabant and the Dombasle, were easier to move with four oxen, and allowed farmers to finish the work quickly before the weather turned. ${ }^{65}$ Larger teams of six or eight oxen were common for certain kinds of work, such as bringing new land into cultivation. ${ }^{66}$ These types of im provements were restricted to large farms, as small farmers, either fixed rent tenants or owner operators, tended to use only cows, since they were cheaper to feed and produced calves that could be sold after a few months and milk that was sold in urban markets. These activities were less risky, but more labour intensive. By contrast, larger farms had a wider selection of animals oxen, bulls, cows and young animals of more than six months (élèves) for meat than small farmers could supply. ${ }^{67}$ Finally, landlords were reluctant to build the expensive new buildings and stalls that would have been required by the division of holdings into smaller farms.

Economies of scale were even greater with other activities such as breed selection and the marketing of the animals, and help explain why most large métairies were part of even larger exploitations or domaines. Each domaine contained about three to five farms and a small area, called the 'reserve', cultivated either by a landlord's agent or a sharecropper. In Mayenne, the domaine often comprised from two to five farms, but many included more than five. ${ }^{68}$ In the Limousin, the average size of the properties studied by Barral was about 140 hectares, and 60 per cent of them were divided into three to six farms, together with the 'reserve'. ${ }^{69}$ The purpose of the reserve was to try out new techniques or crops, to supervise the selection of animals and to keep the expensive machinery for the whole domaine. ${ }^{\mathbf{7 0}}$ Bull breeding was an expensive and risky activity and was not accessible to most small cultivators, who used young bulls or bulls that were commonly available. ${ }^{71}$ The best stabling, pastures and feed were normally kept for these valuable animals, and in most domaines they were not tended by sharecroppers, but by a manager (maître valet), under the direct supervision of the landlord.

It is only at this level that fixed rent farmers, or fermiers généraux, could be found. These farmers acted as middlemen who provided capital, essentially the livestock or a share of them, and were in charge of the supervision of sharecroppers and the marketing of animal products and grain. Once again economies of scale in marketing explain why these farmers were often in charge of more than three farms, sometimes owned by different landlords. Although a single domaine was the norm, a few were very large, and Barral mentions the case of a fermier who cultivated 35 different farms of over a thousand hectares in total held from four different landlords. ${ }^{72}$ 
Theoretically, the fact that landlords were better endowed than tenants with an input that was difficult to trade in, namely managerial expertise, would be another potential justification for using a sharecropping contract. ${ }^{73}$ In the case of France, sharecropping contracts included clauses that allowed the landlord to impose his criteria of general farm manage ment, even without his tenants' consent. ${ }^{74}$ Most decisions that were related to livestock selection, feeding and marketing were under the close scrutiny of landlords or their agents. This point was critical in the debates on the potential advantages (or otherwise) of French sharecropping. While the tenants and their advocates often argued that the landlords' guidance was abusive, was sometimes inefficient or shifted land improve ment costs to them, other writers claimed that it was the main advantage of the contract. ${ }^{75}$ For the defenders of the system, these clauses allowed progressive and wealthy landlords to help their tenants. ${ }^{76}$ The subject was the topic of a parliamentary debate concerning the modification of land tenure in the 1880 s, which finally backed the landlords' case. By contrast, the 1946 reforms shifted influence to the tenants for the first time. ${ }^{77}$

As we have seen earlier, the improvements in farming after 1840 were based on better livestock breeds, new methods of feeding and the intro duction of forage and artificial pastures. In these cases, landlords or their agents often had privileged access to market information and could pro vide better managerial skills. Contemporaries often stressed that the absence of such direction was a hindrance to improvements. ${ }^{78}$ In central and western France this point is particularly important for two reasons. On the one hand, human capital was probably lower in sharecropping areas. If we use literacy as an indicator of human capital, the rate of illit eracy in central France was especially high. The eight French departments with the highest illiteracy rates in 1872 (an average of 62 per cent of con scripts illiterate against a national average of 35.3 per cent) coincided with the highest presence of sharecropping (38.6 per cent against a national average of 13.1 per cent in 1882) ${ }^{79}$ Moreover, in the Limousin, local records confirm that sharecroppers had higher illiteracy rates ( 84 per cent) than other population groups (78 per cent for other cultivators).$^{80}$ This corre lation has been often quoted to show the negative impact of the share cropping contract. ${ }^{81}$ But it seems more likely that high levels of illiteracy were a consequence of rural dispersion, especially high for the inhabitants of métairies. ${ }^{82}$ Sharecroppers' access to information was probably more limited than for tenants of other areas and could be a potential obstacle to adopting new technology. But if the provision of managerial ability can justify sharecropping contracts, it is also important that landlords were 
well disposed to play this role. The fact that many landlords were at the same time predominant members of herd book committees is an indicator that they were not complete absentees. In 1908, the great majority of the 77 landowners who created the 'Société des éleveurs de la race Durham Mancelle' in Mayenne were from the area with most sharecroppers. ${ }^{83}$ Authors more in favour of sharecropping, such as E. Méplain, René Musset or the Comte de Tourdonnet, would stress the importance of the close residence of landlords to their properties, although they often com plained about their lack of interest. ${ }^{84}$ But absentee landlords also had the possibility of renting their land to fermiers généraux, or, increasingly after the First World War, to 'experts', who were agronomists or technicians.

\section{Wage labour, sharecropping and animals}

If economies of scale were so important for cattle raising, and landlords had to impose their will on traditional tenants to introduce farm im provements, they could perhaps have shifted instead to large scale farm ing using wage labour. For Augustin Barral and others, large scale direct farming was a much more efficient way to introduce technological change, although it met resistance from some absentee landlords. ${ }^{85}$ The same author provides examples of large properties of 150300 hectares in the Limousin worked directly by their owners using wage labourers. But if direct cultivation was useful for introducing improvements, landlords usually shifted to sharecropping afterwards. ${ }^{86}$ In fact, and unlike in industrial production, the scope for economies of scale in agriculture was limited given the monitoring costs of labour. ${ }^{87}$ Compared to the large fixed rent farms, with which they were so often compared, sharecropping farms used fewer wage earners. In contrast to the large farmers who specialized in grain crops or livestock fattening, cattle raising as practised in the areas of sharecropping provided greater difficulties for the super vision of wage labour. First, the possibility of substitution of labour for capital was much more limited than in grain farming. The higher labour intensity of production caused by using slow oxen, and the heavy soils, made the substitution of capital for labour especially difficult because of the high cost of maintaining draft animals and the rising cost of labour. Agricultural wages increased by a third in real terms from 1850 to 1885 , and by 40 per cent again from 1885 to $1921 .^{88}$ Secondly, cattle raising required a high share of permanent workers, who were much harder to supervise. Temporary workers, more frequent on the large northern cereal farms, only required close supervision during the harvest operations. ${ }^{89} \mathrm{By}$ contrast, the large graziers in Normandy or the Charollais did not require so much labour because the animals were fattened on natural pastures. 
And third, in the case of mixed farming in large métairies, not only was output more labour intensive, but supervisory skills were crucial to run a wide range of activities all year round. ${ }^{90}$ Irrigated pastures needed the sort of careful and permanent control not required on the fertile pastures in areas such as Normandy or Charollais. Workers had to be attentive to avoid overworking the valuable oxen that were reared for meat. Family workers therefore conferred a real advantage over hired hands, who had to be supervised and could not be easily shifted from one task to another in response to changes in the weather or the existence of idle time. ${ }^{91}$

The problem was how to get a sufficiently large family to work a farm that was twice as large as the average. If the French peasantry started to have small families very early, it seems that sharecroppers were the exception. ${ }^{92}$ In the 1870 s according to Tourdonnet, the average size of a farm in sharecropping over 24 departments was 47 hectares, and it was cultivated by six family workers and only one servant.$^{93}$ Census data from Haute Vienne (Limousin) indicates that sharecropper families were slightly larger than other farming families (5.5 members on average, compared to 4.5 for fixed rent tenants and 3.7 for owner cultivators) but, adjusted to farm size, the average reached 9.3 in the municipality of Eyjaux or 7.5 in Jonchère, where large métairies were the norm. ${ }^{94}$ Even if these large farms usually required some wage labour, it was usually limited to one or two servants. ${ }^{95}$ The farm census of 1946 , which provides details on labour inputs by type of tenure and farm size, shows that even the largest sharecroppers rarely employed more than two farm servants, and a lot of them were relatives who received a salary. ${ }^{96}$ When families were too small to work the largest farms it was always possible to combine related households, although the proportion of extended families ruled by a head of the family was shrinking from the mid nineteenth century. ${ }^{97}$ Large families allowed the provision of different skills according to gender and age. In particular children were able to look after the sheep, pigs and poultry, and do work that was difficult to contract for through the labour market. However, landlords were probably more interested than their tenants in selecting the larger families, or in fixing a minimum amount of work as a clause in the contract. ${ }^{98}$ Large landlords expressed concern about the shrinking size of the sharecropper's family, and about the breaking of family ties that led younger children to look for non farm employment. ${ }^{99}$

IV

The fact that there were advantages for landowners in using share croppers to cultivate their properties does not mean that the organization 
was straightforward. According to Richardson, 'this system does not solve the question as to what is the best relation in which landlords and tenants should stand towards each other'. ${ }^{100}$ Supervising tenants in com plex systems involving crop rotation, livestock and a variety of products, even if it was cheaper than contracting wage labourers, was not particu larly easy. The contracts were normally very complex. While some of the details are sometimes considered to be examples of the exploitative character of the contract, or as feudal residues, these were, as we will see, often more appropriately explained in terms of the high monitoring costs required to implement the clauses of the contract. There were two par ticular problems that the contract had to address: the sharing of inputs and work by both landlord and tenant, and the division of the product. Input sharing can create problems of moral hazard, but as I have argued, sharecropping was often a more efficient way to deal with the difficulties than was fixed rent tenancy. In contrast, the division of the output was a potential source of cheating that could be sufficiently serious to preclude the adoption of the contract.

With respect to inputs, the landlords usually provided the land, the livestock and increasingly a large share of the most expensive machinery. The tenant in turn supplied all of the permanent labour, usually a share of the seasonal labour, all hand tools and sometimes a share of the livestock. Inputs such as fertilizers or seeds were normally shared in halves or in other proportions usually more favourable for the tenant. Fixed invest ment such as in liming or buildings was usually financed by landlords, although tenants had to provide the labour. Allen and Lueck have argued that the main advantage of sharecropping over fixed rent farming is that it avoids the transaction costs of supervising the correct use of the landlord's inputs. ${ }^{101}$ Since inputs were shared, sharecroppers were less prone to make an excessive use of land or to overwork the draught livestock. ${ }^{102}$ In addition the landlord could stipulate the amount of fertilizer to be used, the feed for the livestock and the crop rotation on the arable land.

Share contracts included clauses related to the distribution of pro duction. Normally the landlord and tenant shared any increase (or decrease) in the value of the livestock and the proceeds from the sale of livestock and cereals (rye and increasingly wheat) and any other products that were divided in kind after the harvest. However, not all products were divided equally. Forage and root crops were usually fed to the livestock and the garden produce was for the sharecropper and his own family's consumption. For others, the landlord had the right to a fixed amount of the product, such as a certain number of pigs, poultry, bags of chestnuts or potatoes and so on. When the output was an annual crop, such as grapes or grains, it was relatively easy for the landlord or his agent to 
control the harvest. This observation could be extended to rice or olive production. However, mixed farming allowed for a large variety of pro ducts: grains, potatoes, fodder, fruit, chestnuts, and so on, and also a large variety of animal products, meat, poultry, wool, milk, butter, eggs, etc. If some products were obtained only once a year, other goods such as fruit or dairy products were more frequent. Cows had to be milked daily, and the milk could be consumed in different ways fresh, as butter, or fed to the young cattle. Potential problems of opportunistic behaviour, such as under reporting the daily production and selling the surplus, were likely, and explain why sharecroppers were not allowed to produce butter or milk for the market until the late 1890s, when the development of butter cooperatives allowed landlords the possibility of securing an accurate monthly account of production. Contracts were drawn up with an evident sensitivity to the importance of the transaction costs associated with the division of output, which explains why the clauses were limited to the division of only two or three products, namely the most valuable or the easiest to measure. Garden produce and most of the animal feed were allowed to be consumed by the sharecroppers or their livestock, but could never be sold. ${ }^{103}$ This feature helps explain why sharecropping was often considered as self sufficient although personal consumption was often not high. According to the figures of Garidel, the consumption of the farm's products by the tenants on five farms in the Allier between 1875 and 1879 was only about 7 to 10.5 per cent of the gross product. ${ }^{104}$ In other cases the landlords were aware of the importance of close and strict monitoring of the division of production: cattle were normally sold in the presence of both sides, often in the market and the harvest was indirectly supervised through the wage labourers employed by the landlord. Other clauses required fixed payments, such as a bag of potatoes or chestnuts, thirty eggs, a pound of butter, one or two pigs, to minimize supervision costs.

Transaction costs could also be reduced in other ways. Landlords who were especially involved in the management of their holdings or their livestock could reduce their marginal cost of supervision of labour, and as I showed earlier, the stock usually belonged to them in the region specialized in cattle raising. Long term contracts or annual renewals over several generations were other means employed to build up relationships based on trust that reduced the risk of cheating. ${ }^{105}$ Collection of data on the length of contracts is particularly difficult, but it is possible to infer that the new opportunities for sharecroppers to buy land in the 1880s or after the First World War would have broken this old relationship, and reduced the social capital that landlords enjoyed in previous decades.

This question is important from the point of view of whether the con tract would have suffered from a lack of trust between the two parties. 
Given the complexity of mixed husbandry, and the sharing of decisions related to the purchase of inputs, investment in building or livestock selection, the possibility of conflicts was likely to be high. Some clauses were actually bitterly resented and considered as feudal residues from the past. In addition, in the Allier and some other areas before the First World War, most sharecroppers had to pay a fixed amount of money, l'impôt colonique (the tenant tax), of around 10 per cent of the gross product, to compensate the landlord for any improvements in land pro ductivity that were not due to the tenant's efforts. ${ }^{106}$ The abolition of l'impôt colonique, among other claims, mobilized for the first time a large number of sharecroppers of the Allier in 1905 and stimulated the creation of the 'Fédération des Travailleurs de la Terre', a trade union for share croppers and agricultural labourers. But this kind of conflict was excep tional in France. ${ }^{107}$ A possible explanation for the absence of conflict is the fact that the contract was able to adapt to the rising opportunity cost of labour. Contracts were modified in order to progressively increase the tenant's share of the output during the first half of the twentieth century. When a law of 1946 made compulsory a reduction of one half to one third of the total product to be paid to the landlord, many tenants were already paying roughly this share. ${ }^{108}$ Thus, the flexibility of adjustments over time, and the fact that the contract tended to minimize the transaction costs associated with output measurement, probably compensated for the potential conflicts between the economic agents.

\section{CONCLUSIONS}

In this article I have addressed the question of why certain French land lords preferred to use sharecropping contracts rather than fixed rent ones. We have seen that most of these landlords could be found in regions where specialization in livestock was important, especially in cattle rearing and meat production. Farmers lacked sufficient physical and human capital to farm the large holdings. This explains the importance of land lords' managerial expertise for the choice of share contracts. However, the complexity of mixed farming also required a quality of work and certain organizational skills that would have been too expensive with wage labour. While sharecropping farmers employed a large share of the servants who worked in the main sharecropping areas of central and western France, landowners still preferred to rent their holdings to large families capable of supplying most of the required labour. Finally, supervising tenants in complex systems involving crop rotation, livestock rearing and a variety of other products was not easy, and consequently the contracts carried complex and detailed clauses. Whereas sharecroppers felt the unfairness 
of many such clauses, most of them served to minimize transaction costs. In contrast with the traditional view, which favoured fixed rent tenancy rather than sharecropping for large scale cultivation, sharecropping was, paradoxically, the agricultural contract that allowed landowners in central and western France to maintain large scale livestock farming in a context of increasing numbers of small owner operators and fragmentation of holdings.

\section{AKNOWLEDGEMENTS}

I wish to thank the Spanish government for the funding it provided (BEC2003-06481 and PR2002-0080) and am grateful for the comments and advice of James Simpson and the referees of the journal. The article also benefited from criticism given at the seminar 'Sharecropping in History' which took place at the University of Madeira in October 2004. Any errors and omissions are all of my own making.

\section{ENDNOTES}

1 X. Planhol, Géographie historique de la France (Paris, 1988), 180; A. Fel, 'Petite culture, 1750 1850', in H. Clout ed., Themes in the historical geography of France (London, 1977), 238 43; G. Duby and A. Wallon eds., Histoire de la France rurale (Paris, 1975 1976), vol. 3, 298.

2 P. O'Brien, 'Path dependency, or why Britain became an industrialized and urbanized economy long before France', Economic History Review 49 (1996), 213 49, here 214; E. Weber, Peasants into Frenchmen: the modernization of rural France, 18701914 (Stanford, 1976), 189 90; G. Postel-Vinay, 'L'agriculture dans l'économie française: crises et réinsertion', in M. Lévy-Leboyer and J. C. Casanova eds., Entre l'état et le marché (Paris, 1991), 52 92, here 745.

3 D. Ray, Development economics (Princeton, 1999); Y. Hayami and K. Otsuka, The economics of contract choice (Oxford, 1993); P. Hoffman, Growth in a traditional society (Princeton, 1996).

4 A. de Gasparin, Mémoire sur le métayage (Paris, 1832); Conseil Economique et Sociale, Les diverses formes de métayage (Paris, 1953); J. Carmona and J. Simpson, 'The "rabassa morta" in Catalan viticulture: the rise and decline of a long term sharecropping contract, 1670s 1920s', Journal of Economic History 59 (1999), 290 315; P. Hoffman, 'The economic theory of sharecropping in early modern France', Journal of Economic History 42 (1984), 155 62; F. Galassi and J. Cohen, 'The economics of tenancy in early twentieth-century Southern Italy', Economic History Review 47 (1994), 585600.

5 Métairie is a term that included not only sharecropping tenures but also any substantial peasant holdings.

6 Hoffman, 'The economic theory', 155 6; L. Merle, La métairie et l'évolution agraire de la Gâtine poitevine de la fin du Moyen Age à la Révolution (Paris, 1958).

7 M. L. Lavergne, L'économie rurale de la France depuis 1789 (Paris, 1857), 164; Gasparin, Mémoire, 15; A. Mahul, Considérations sur l'économie et sur la pratique de l'agriculture (Paris, 1846); L. de Dreuille, Du métayage et des moyens de le remplacer (Paris, 1865); F. Pariset, Economie rurale, industrie, moeurs et usages de la Montagne noire (Carcassone, 1882). 
8 Dreuille, Du métayage, 14; L. Ladoucette, De l'influence des divers modes de location sur le produit des terres en France (Paris, 1844), 15963.

9 Dreuille, Du métayage, 36 7; Pariset, Economie rurale, 39.

10 A. Méplain, Traité de bail à portion de fruit ou colonage partiaire (Moulins, 1850), 173.

11 M. Augé Laribé, La politique agricole de la France de 1880 à 1940 (Paris, 1950), 96 7; Planhol, Géographie, 180; Fel, 'Petite culture', 215 45; Weber, La fin des terroirs.

12 C. de Tourdonnet, Traité pratique du métayage (Paris, 1882), XI; L. Rerolle, Du colonnage partiaire et spécialement du métayage (Paris, 1888), 535 6; La Société des agriculteurs de France, Congrès du métayage. 20 et 21 février 1939 (Paris, 1939), 154, 1601.

13 S. Sokoloff, 'Land tenure and political tendency in rural France: the case of sharecropping', European Studies Review 10 (1988), 35782.

14 Hoffman, Growth, 669.

15 D. Ackerberg and M. Botticini, 'The choice of agrarian contracts in early Renaissance Tuscany: risk sharing, moral hazard or capital market imperfections?', Explorations in economic history 37 (2000), 241 57; D. Allen and D. Lueck, 'Contract choice in modern agriculture: cropshare versus cash rent', Journal of Law and Economics 35 (1992), 397 426; L. Alston and R. Higgs, 'Contractual mix in Southern agriculture since the Civil War: facts, hypothesis, and tests', Journal of Economic History 42 (1982), 32754.

16 Hayami and Otsuka, The economics, 649.

17 G. Grantham, 'Scale and organization in French farming, 1840 80', in W. Parker and E. Jones eds., European peasants and their markets (Princeton, 1975), 23692.

18 For Mayenne, see R. Salabert, La Mayenne des origines à nos jours (SaintJean-d'Angély, 1984), 227; for Gâtine, see J. Peret, Les paysans de Gâtine poitevine au XVIIIe siècle (Poitiers, 1996), 126.

19 Each 'Région agricole' covers an area of about 1,000 square kilometres with a common geographical trait.

20 Ministère de l'Agriculture, Résultats généraux de l'enquête de 1892 (Paris, 1897), 21825.

21 Conseil Economique, Les diverses formes, vol. 1, 92105.

22 Ibid., 83.

23 Ibid., 846.

24 Ibid., 12.

25 E. Quittet mentions the following breeds, specialized for meat and work: Charolaise, Blonde des Pyrénnées, Garonnaise, Maine-Anjou, Parthenaise, Salers, Bazadaise and Aubrac y Gasconne. Except for Salers in Cantal, where there was not much sharecropping, the others are located in sharecropping areas; see Races bovines francaises (Paris, 1963). See also Conseil Economique et Sociale, Les diverses formes, vol. 1, 845.

$26 \mathrm{H}$. Farcy, 'La repartition géographique des modes de faire valoir en France', Revue de Géographie de Lyon (1951), 229 41, here 238. Spindler would take the relation further and suggests that cattle rearing was endogenous to sharecropping; see 'Les races bovines à viande: un produit du métayage. L'influence du métayage sur l'orientation de l'élevage en France', Ethnozootechnie 57 (1996), 15 24, here 15.

27 In Nièvre, Saône-et-Loire and Maine-et-Loire, the sharecropping contract was only very important in a few cantons.

28 G. Grantham, 'Agricultural supply during the industrial revolution: French evidence and European implications', Journal of Economic History 49 (1989), 43 72, here 567.

29 F. Spindler, Un siècle et demi d'élevage en France (Paris, 1991), 151.

30 Lavergne, L'économie rurale, 301.

31 A. Husson, Les consommations de Paris (Paris, 1875), 194200. 
32 P. Bossis, 'Le laboureur des bocages du Centre-Ouest, principalement au XVIIIè siècle', in A. Antoine ed., Campagnes de l'Ouest: stratigraphie et relations sociales dans l'histoire (Rennes, 1999), 393 405, here 397.

33 O. Delafond, Études sur les rendements du gros bétail de boucherie primé dans les concours nationaux de Poissy, Lyon, Bordeaux et les animaux engraissés dans les bouveries nationales (Paris, 1851).

34 Lavergne, L'économie rurale, 12; G. G. Richardson, The corn and cattle producing districts of France (London, 1877), 92. Even Arthur Young admitted that 'there is not better beef in the world than in Paris'; quoted ibid., 95.

35 Delafond, Études, 24 5; M. Baillet, La statistique et l'inspection des viandes de boucherie (Bordeaux, 1886), 5.

36 L. Villain and V. Bascou, Manuel de l'inspecteur des viandes (Paris, 1890), 129 30. Light work allows fat to enter the muscle.

37 A. Thuillier, Economie et société nivernaises au début du XIXè siècle (Paris, 1974), 88.

38 J. Wilson, British farming: a description of the mixed husbandry of Great Britain (Edinburgh, 1862), 421.

39 Spindler, Un siècle et demi, 153.

40 J. Risse, Histoire de l'élevage français (Paris, 1994), 155; Delafond, Études, 30; L. de Lavergne, L'agriculture et la population (Paris, 1857), 11. The importance of the experiments made by landlords is stressed in Spindler, Un siècle et demi, 158 .

$41 \mathrm{~J}$. de Garidel, Lettres sur la pratique du métayage dans le département de l'Allier avec monographie de six domaines exploités à moitié fruits (Moulins, 1881), 24.

42 J.-A. Barral, L'agriculture, les prairies et les irrigations de la Haute-Vienne (Paris, 1881).

43 For example, the Propiété de Roulhac, ibid., 4013.

44 Ibid., 43, 51, 52.

45 Ministère de l'Agriculture, Enquête sur les engrais industriels (Paris, 1865), vol. 1, 7667.

46 See C. Toutain, La production agricole de la France de 1810 à 1990: départements et régions: croissance, productivité, structure, économies et sociétés (Grenoble, 1992 1993), vol. 3, 912 14, 991 4, 9236 and 956 68; and J. Pautard, Les disparités régionales dans la croissance de l'agriculture française (Paris, 1965), 42.

47 Barral, L'agriculture, 419.

48 Garidel, Lettres, 1887.

49 P. Caziot, La valeur de la terre en France, description des grandes régions agricoles et viticoles, prix et fermages des bien ruraux (Paris, 1914), 2235.

50 Ibid., 2868 for the Limousin, 292 for Poitou and 140 for Normandy.

51 Ackerberg and Botticini, 'The choice', 2423.

52 Tourdonnet, Traité, 242 4; Garidel, Lettres, 15.

53 According to G. Postel-Vinay, the average for France was roughly around 150 and 300 francs between 1860 and 1880; see 'L'agriculture', 63.

54 G. Postel-Vinay, La terre et l'argent; l'agriculture et le crédit en France du XVIII au début du XX $X^{e}$ siécle (Paris, 1996), 1856.

55 An exemple in A. Méplain, Histoire d'un domaine du département de l'Allier et du Gran Jacquet métayer (Moulins, 1868).

56 Tourdonnet, Traité, 283.

57 Garidel, Lettres, 229.

58 One hectare of land would cost about 1,200 to 1,400 francs in 1879; see Caziot, $L a$ valeur, 225. For the 1860s, see Garidel, Lettres, 24. On the success of peasant property in the first decade of the twentieth century see Ministère de l'Agriculture, La petite propriété rurale en France: enquêtes monographiques (1908 1909) (Paris, 1909); for the 1930s, see P. Rouveroux, Le métayage: ce qu'il faut en savoir (Paris, 1935), 115. As 
Sokoloff has observed, 'the attraction of independence and the almost mythic appeal of land to the sharecropper cannot be sufficiently emphasized'; Sokoloff, 'Land tenure', 368.

59 P. Dubost, Le métayage en Bourbonnais pendant la guerre et son avenir (Paris, 1920), 1678.

60 Thus in 1953 most landlords would still contribute the whole stock or the majority of it; see Conseil Economique et Sociale, Les diverses formes, vol. 1, 1212.

61 Grantham, 'Scale', 2946.

62 Ministère de l'Agriculture, La petite propriété rurale; R. Price, 'The onset of labour shortages in nineteenth-century French agriculture', Economic History Review 28 (1975), 276.

63 H. Levy, Large and small holdings: a study of English agricultural economics (London, 1966), 1046.

64 Ministère de l'Agriculture, La petite propriété, 26972.

65 Garidel, Lettres, 59 60. The Dombasle plough needed bigger draft animals, Grantham, 'Scale', 304.

66 Ministère de l'Agriculture, Monographie agricole du département de la Vendée (Paris, 1937), 235.

67 Chatrons (young oxen) were still reared on large sharecropping farms in 1959; see Ministère de l'Agriculture, Monographies agricoles départementales (Paris, 1959), vol. 1, 56.

68 Ministère de l'Agriculture, Monographies, 65.

69 Barral, L'agriculture, 5079.

70 Ibid., 508 9; Tourdonnet, Traité, 2239.

71 Wilson, British farming, 418. According to Levy, English large farmers had almost a monopoly of bull-breeding; see Large and small holdings, 17980.

72 Barral, L'agriculture, 251.

73 E. Sadoulet, R. Murgay and A. de Janvry, 'Access to land via land rental markets', in A. Janvry et al. eds., Access to land, rural poverty and public action (Oxford, 2001), 208 9; J. Reid, 'Sharecropping as an understandable market response: the post-bellum South', Journal of Economic History 33 (1973), 106 30, here 1256.

74 For Mayenne, see R. Salabert, La Mayenne des origines à nos jours (SaintJean-d'Angély, 1984), 300; for the Allier, see A. Compère-Morel, La question agraire et le socialisme en France (Paris, 1912), 645 and 83; for Haute Vienne, see Recueil des usages locaux à caractère agricole du Département de la Haute Vienne (Limoges, 1942), 18.

75 E. Guillaumin, La vie d'un simple (mémoires d'un métayer) (Paris, 1904).

76 Tourdonnet, Traité, 58.

77 Conseil Economique et Sociale, Les diverses formes, 15963.

78 Tourdonnet, Traité, 150 1. E. Demolins, Les français d'aujourd'hui: les types sociaux du Midi et du Centre (Paris, 1898), 293.

79 Statistique de la France, Résultats généraux du dénombrement de 1872 (Nancy, 1874).

80 A. Corbin, Archalsme et modernité en Limousin au XIXe siècle. 18451880 (Limoges, 1998), 333.

81 X. Planhol, Géographie historique de la France (Paris, 1988), 17980.

82 J. R. Trochet, Aux origines de la France rurale (Paris, 1993).

83 Spindler, Un siècle et demi, 103.

84 E. Méplain, Traité du bail à portion de fruits ou colonage partiaire (Moulins, 1850), 169 70; R. Musset, Le Bas-Maine: études géographique (Paris, 1917), 327; C. de Tourdonnet, Situation du métayage en France: rapport sur l'enquête ouvert par la Société 
des Agriculteurs de France (Paris, 1879 1880), 99. Absentee landlords were more common in northern France. Demonet, Tableau de l'agriculture francaise au milieu du XIXe siècle (Paris, 1990), 44.

85 Tourdonnet, Traité, XVII; Barral, L'agriculture, 50910.

86 On the disappearance of the 'régie' in Allier, see L. Larminat, Etudes sur le métayage dans le département de l'Allier (Moulins, 1881), 78.

87 Hayami and Otsuka, The economics, 13.

88 Duby and Wallon, Histoire, vol. 3, 21218.

89 Demonet, Tableau, 65.

90 Levy, Large and small holdings, 15471.

91 G. Grantham, 'The diffusion of the new husbandry in northern France', Journal of Economic History 38 (1978), 311 37, here 318.

92 J. Dupaquier, Histoire de la population française (Paris, 1991), vol. 3, 37882.

93 Tourdonnet, Situation du métayage en France, 35163.

94 Archive Départementale de la Haute-Vienne, 6 M 11, 88 and 106.

95 Ibid.

96 Large farms in the Sologne (50 100 hectares) or Basse Marche (over 70 hectares), where share contracts occupied 76 and 87 per cent of the land, used 2.5 and 1.2 servants per farm, whereas Montagneuse with less than 40 per cent, the medium farms of Basse Marche ( $47 \%$ in share) or Haut-Limousin (less than $1 / 3$ in share) used only 0.4 servants. See Institut Nationale de la Statistique et des Études Économiques, Résultats statistiques du recensement général de la population effectué le 10 mars 1946, vol. VII: Exploitations agricoles (Paris, 1950).

97 Garidel, Lettres, 27.

98 For instance in the Allier; see Compère-Morel, La Question agraire, 66, and Garidel, Lettres, 63.

99 Garidel, Lettres, 64 5; Tourdonnet, Traité, 1012.

100 Richardson, The corn and cattle, 231.

101 Allen and D. Lueck, 'Contract choice', 397426.

102 F. Galassi and K. Kauffman, 'The economics of draft animal choice in Italian agriculture: a principal agent approach to the adoption of an early form of capital', Journal of European Economic History (1997), 375 95, here 3823.

103 Ministère de l'Agriculture, Monographie agricole du département de la Haute-Vienne (Paris, 1937), 213.

104 Garidel, Lettres, 11.

105 Hayami and Otuka, The economics, 5669.

106 Sokoloff, 'Land tenure', 3667.

107 Compared to Catalonia, for instance; see Carmona and Simpson, 'The "rabassa morta",, 290315.

108 Conseil Économique et Sociale, Les diverses formes, vol. 2. 